\title{
Splenectomy and its relation to non-transfusion- transmitted infection in thalassemic patients
}

\author{
Mururul Aisyi, Alan Roland Tumbelaka, Bulan Ginting Munthe, Bambang Madiyono
}

\begin{abstract}
Background Splenectomy has been associated with an increased susceptibility to infection. Overwhelming postspelenectomy infection (OPSI) can lead to high mortality. Decreased IgM and tuftsin concentration on splenectomized patients seems to play a role in infection's susceptibility. Many studies have been performed to determine the risk factors of infection in thalassemic patients.

Objective To find out morbidity patterns and risk factors for predicting the likelihood of infection in splenectomized thalassemic patients.

Methods A retrospective cross sectional study was conducted on confirmed thalassemic children who came to Department of Child Health, Cipto Mangunkusumo Hospital within the period of 19732003. Splenectomized patients were categorized as cases group and non-splenectomized patients as control group. Risk factors for development of common cold and diarrhea were analyzed using chi-square test with level of significance $<0.05$.

Results A total of 300 thalassemic patients, 100 of them were splenectomized, were enrolled in this study. The 15-year-age group or above is the most common group underwent splenectomy (35\%). Common cold is the most common mild infection in both splenectomized group $(75 \%)$ and non-splenectomized $(71 \%)$. A significant association was found between the risk of infection and splenectomy in thalassemic patients $(\mathrm{OR}=3.8 ; \mathrm{Cl}=2.2 ; 6.62 ; \mathrm{P}=0.000)$. Association between time after splenectomy and frequency of common cold in thalassemia was significant $(O R=2.85 ; \mathrm{Cl}=1.16 ; 7.14$; $\mathrm{P}=0.011$ ). Severe infection and acute diarrhea were considered not significantly different between the two groups.

Conclusion Splenectomy in thalassemia can increase the susceptibility of non-transfusion-transmitted mild infection. Further study is needed to elaborate this finding [Paediatr Indones 2006;46:134-138].
\end{abstract}

Keywords: splenectomy, thalassemia, non transfusion-transmitted infection, risk factors, mild infection

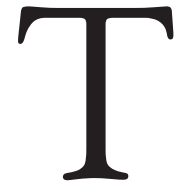

halassemia is a hereditary hemoglobin synthesis defect that was first depicted by Cooley and Lee in 1925. ${ }^{1}$ In Indonesia, gene carrier of thalassemia is about $5 \%$ which results in an estimation of 5000 new cases every year. ${ }^{1-3}$ Infection ranks second after cardiac failure as causes of death among thalassemic patients. There are usually more than one predisposing factors which pose a thallasemic patient to an increased risk of infection. ${ }^{4}$ Splenectomized patient are easily infected because they no longer have spleen's benefit of phagocytosis and antibody factors. The predisposition of splenectomized patient to infection with encapsulated bacteria is well-documented. The objective of our study was to find out the effect of splenectomy in thalassemic patients to susceptibility of infection in Department of Child Health, Cipto Mangunkusumo Hospital.

\section{Methods}

A retrospective analytic cross sectional study was carried out on thalassemic children treated in Department of Child Health, Cipto Mangunkusumo

From the Department of Child Health, Medical School, University of Indonesia, Jakarta, Indonesia.

Reprint requests to: Mururul Aisyi, MD, Medical School, Department of Child Health, Faculty of Medicine University of Indonesia, Cipto Mangunkusumo Hospital, Jl. Salemba 6, Jakarta, Indonesia. Tel. 62-213907742. Fax.62-21-3907743. Email: aisyi@hotmail.com 
Hospital, during the period of 1973-2003. Enrollment criteria were children who had been diagnosed as thalassemia and had complete data. Splenectomized patients were determined as case group, and nonsplenectomized patients appropriate for age and gender were served as control group. Patients with incomplete data and transfusion-transmitted infections (such as hepatitis and AIDS) were excluded. Control group was chosen using randomized stratified sampling.

Sample size was calculated according to case control match formula; resulting in a total sample of 300 patients, including 100 patients who have undergone splenectomy. Calculation of odds ratio was performed to find correlation between risk factors and the development of infections. All statistical procedures were done using SPSS 12.00 for Windows. The study was approved by the Committee for Medical Research Ethics of the Medical School, University of Indonesia.

\section{Results}

There were 102 children diagnosed as thalassemia who had undergone splenectomy, but only 100 were included in this study. Two hundred patients had been chosen as control based on sex and age. The 15-year-age or above group is the most common group underwent splenectomy (35\%). Splenectomy was rarely performed in the $1-4$ year age group (5\%). On the other hand, splenectomy is more frequent on male (52\%) rather than female $(48 \%)$. Control group has the same sex and age proportion.

Common cold is the most common mild infection in both splenectomized (76\%) and non-splenectomized (71\%) groups. On the second rank was acute diarrhea in either splenectomy $(9 \%)$ or non-splenectomy $(10 \%)$ group. Other infections include furunculosis, cutaneus abcess, varicella, and gingivitis. Only 1 case of parotitis was found in splenectomized group (Table 1).

Infections more commonly occurred in subjects with splenectomy than in those without splenectomy. Children aged $\geq 5$ years revealed to have more infections in both groups. Mild infection more commonly occurred in splenectomized patients; there were more subjects without infection in the non-splenectomized thalassemic group (Table 2).

TABle 1. Non-transfussion-mediated mild INFECtion IN SPLENECTOMIZEd AND NONSPLENECTOMIZED THALASSEMIC PATIENT

\begin{tabular}{lcccccc}
\hline \multirow{2}{*}{ Mild infection } & \multicolumn{3}{c}{ Splenectomy } & \multicolumn{3}{c}{ Non-splenectomy } \\
\cline { 2 - 6 } & Male & Female & Total & Male & Female & Total \\
& $\mathbf{n}(\%)$ & $\mathbf{n}(\%)$ & $\mathbf{n}(\%)$ & $\mathbf{n}(\%)$ & $\mathbf{n}(\%)$ & $\mathbf{n}(\%)$ \\
\hline Common cold & $30(67)$ & $32(86)$ & $62(76)$ & $50(74)$ & $37(67)$ & $87(71)$ \\
Acute diarrhea & $6(13)$ & $2(5)$ & $8(10)$ & $9(13)$ & $4(7)$ & $13(11)$ \\
Furunculosis & $4(9)$ & $1(3)$ & $5(6)$ & $5(7)$ & $7(13)$ & $12(10)$ \\
Cutaneus abcess & $1(2)$ & $0(0.00)$ & $1(1)$ & $2(3)$ & $0(0)$ & $2(16)$ \\
Varicella & $2(4)$ & $0(0.00)$ & $2(2)$ & $2(3)$ & $2(36)$ & $4(3)$ \\
Gingivitis & $1(2)$ & $2(5)$ & $3(4)$ & $0(0)$ & $2(36)$ & $2(16)$ \\
Parotitis & $1(2)$ & $0(0)$ & $1(1)$ & $0(0)$ & $0(0)$ & $0(0)$ \\
Total & 45 & 37 & 82 & 68 & 55 & 123 \\
\hline
\end{tabular}

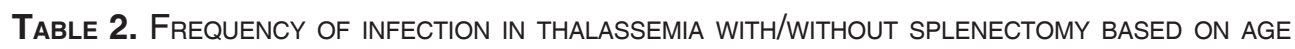
GROUP

\begin{tabular}{lcccccc}
\hline \multicolumn{1}{c}{$\begin{array}{c}\text { Age } \\
\text { (years) }\end{array}$} & \multicolumn{3}{c}{ Splenectomy } & \multicolumn{3}{c}{ Non -splenectomy } \\
\cline { 2 - 6 } & $\begin{array}{c}\text { Without } \\
\text { infection } \\
(\%)\end{array}$ & $\begin{array}{c}\text { Mild } \\
\text { infection } \\
(\%)\end{array}$ & $\begin{array}{c}\text { Severe } \\
\text { infection } \\
(\%)\end{array}$ & $\begin{array}{c}\text { Without } \\
\text { infection } \\
(\%)\end{array}$ & $\begin{array}{c}\text { Mild } \\
\text { infection } \\
(\%)\end{array}$ & $\begin{array}{c}\text { Severe } \\
\text { infection } \\
(\%)\end{array}$ \\
\hline $1-4$ & $0(0)$ & $5(5)$ & $0(0)$ & $1(1)$ & $9(4)$ & $1(1)$ \\
$5-9$ & $5(5)$ & $22(21)$ & $1(1)$ & $25(12)$ & $29(14)$ & $1(1)$ \\
$10-14$ & $7(7)$ & $26(25)$ & $1(1)$ & $33(16)$ & $33(16)$ & $0(0)$ \\
$\geq 15$ & $12(12)$ & $23(22)$ & $1(1)$ & $50(25)$ & $20(10)$ & $1(1)$ \\
Total & $24(23)$ & $76(74)$ & $3(3)$ & $109(54)$ & $91(45)$ & $3(2)$ \\
\hline
\end{tabular}


A significant association was found between the risk of infection (mild \& severe) with splenectomy in thalassemic patients $(\mathrm{P}<0.001)$. Odds ratio was 3.8 $(\mathrm{CI}=2.26 ; 6.62)$ (Table 3). On the other hand, there was no association between severe infection and splenectomy in thalassemic patients $(\mathrm{P}=0.404)$.

Table 3. Infection (mild and seVere) in SPLenectomized AND NON-SPLENECTOMIZED PATIENTS

\begin{tabular}{lccl}
\hline \multicolumn{3}{c}{ Splenectomy } & Non-splenectomy \\
\hline $\begin{array}{l}\text { Infection } \\
\text { (mild \& severe) }\end{array}$ & 76 & 91 & $\begin{array}{l}\mathrm{OR}=3.8 \\
(\mathrm{Cl}=2.2 ; 6.62)\end{array}$ \\
$\begin{array}{l}\text { Without } \\
\text { infection }\end{array}$ & 24 & 109 & $\mathrm{P}<0.00001$ \\
\hline
\end{tabular}

There was a significant correlation between the frequency of common cold and splenectomy detected during the first two years after the procedures. (Table 4)

TABLE 4. THE RISK OF COMMON COLD DURING the FIRST 2 YEARS AFTER SPLENECTOMY

\begin{tabular}{lccl}
\hline \multicolumn{3}{c}{ Splenectomy } & Non-splenectomy \\
\hline $\begin{array}{l}\text { Frequent } \\
(>1-8 x / \text { year })\end{array}$ & 22 & 4 & $\begin{array}{l}\mathrm{OR}=13.8 \\
(\mathrm{Cl}=4.6 ; 41.4)\end{array}$ \\
$\begin{array}{l}\text { Rare } \\
(<1 \mathrm{x} / \text { year })\end{array}$ & 78 & 196 & $\begin{array}{l}\mathrm{P}<0.0001 \\
\mathrm{RR}=2.97\end{array}$ \\
\hline
\end{tabular}

We did not find any significant association between acute diarrhea and time of splenectomy. Furthermore, association between time after splenectomy and frequency of common cold on thalassemia was significant $(\mathrm{OR}=2.85 ; \mathrm{CI}=1.16 ; 7.14 ; \mathrm{P}=0.011)$ (Table 5).

Table 5. Relation between time after splenectomy With COMMON COLD ON THALASSEMIA

\begin{tabular}{lccl}
\hline & $\mathbf{\leq 2}$ years & $\mathbf{> 2}$ years & \\
\hline Frequent $(\leq \mathbf{1 - 8 x} /$ year) & 22 & 9 & $\begin{array}{l}\mathrm{OR}=2.85 \\
(\mathrm{Cl}=1.16 ; 7.14)\end{array}$ \\
& & & $\begin{array}{l}\mathrm{P}=0.011 \\
\mathrm{RR}=2.97\end{array}$ \\
Rare ( $\leq 1 \mathrm{x} /$ year) & 78 & 91 & \\
\hline
\end{tabular}

\section{Discussion}

This study has some limitations. A lower morbidity rate recorded than that actually occurred is a possibility, due to the fact that not all patients went to the outpatient clinic of Cipto Mangunkusumo Hospital on the event of infections. However, as randomized stratified sampling was employed, those frequencies in case and control group are remained able to be compared. Other predisposing factors of infection such as iron overload, anemia and fagocyte function were not included in this research, which could make some bias. Monocytes from patients with thalassemia major have intracellular defect in their microbicidal mechanisms in association with iron overload. Neither splenectomy nor chelating agent therapy can reverse this impairment. This cell dysfunction could be responsible, at least in part, for the increased susceptibility to infections in thalassemia major. ${ }^{5}$

According to Wanachiwanawin, ${ }^{4}$ it is also likely that each patient with thalassemia who develops infection has more than one predisposing factors. These include splenectomy, iron overload, severity of anemia, and phagocyte dysfunctions.

On age basis, splenectomy is more commonly performed at 15 years or above (35\%). Increased transfusion requirement, mentally and financially readiness of parents, and relatively easier operation technique are some attributing factors of this finding. Indication of splenectomy in our cases was early hypersplenism defined as increased transfusion requirement above $200 \mathrm{ml} / \mathrm{kg} /$ year.

Most common non-transfusion-mediated mild infections in both splenectomized and non-splenectomized group were quite similar. Common cold and acute diarrhea were the most common findings in both groups. Others included furunculosis, cutaneus abcess, varicella, gingivitis, and parotitis in relatively similar proportion in both groups. Wanachiwanawin's study, ${ }^{4}$ found common cold and acute gastroenteritis also commonly occured in thalassemia. Shaiegan ${ }^{6}$ reported defective neutrophil function in thalassemia major patients that lead them to increased susceptibility to infection. Chemotactic and random migrations were also found to be defective. ${ }^{?}$

The complications of splenectomy, especially the overwhelming post splenectomy infection, are well known. Unlike Wanachiwanawin's report, we found a very low incidence of severe infection with no differences in both groups. Typhoid fever and cellulities were found on splenectomized group. Septicemia and pneumonia, two most common severe infections were not found in our cases. A study by Wanachiwanawin ${ }^{4}$ reported that $75 \%$ thalassemic patients with severe infection had had splenectomy. Our findings are different from Wanachiwanawin due to the fact that, in our 
sample, splenectomy rarely performed below 5 year-old. Styrt ${ }^{8}$ found severe infection after splenectomy particularly happened before 2 year-old. The principal disadvantage of splenectomy is the loss of patient's ability to respond immunologically to intravenous antigen. The spleen's unique vasculature allows prolonged contact between blood and phagocytes to permit the processing of intravenous antigen especially the encapsulated bacteria. This function is very important in young children when levels of passively transmitted maternal antibody decline at $4^{\text {th }}-6^{\text {th }}$ month and active immunity to these organisms develops slowly. ${ }^{9}$

The lower rates of post-splenectomy sepsis found in more recent studies may reflect the use of prophylactic penicillin, immunization with pneumococcal vaccine, and delayed splenectomy beyond the age of 3 years. ${ }^{10}$ Lynch $^{11}$ reported 2 cases of life-threatening infection in thalassemia suggesting that children with thalassemia should be managed properly. With careful perioperative management and proper follow-ups, splenectomy in patients with hematological diseases is safe and beneficial in reducing transfusion requirements and its attendant risks. ${ }^{12,13}$

Infections attributed to splenectomy are acute and fulminant, and there may be septicaemic diseases that often lead to death within hours of the first symptoms. The spleen is an important source of opsonins and a site for the synthesis of specific antibodies and the regulation of both $\mathrm{T}$ and $\mathrm{B}$ lymphocytes. ${ }^{14}$ Lynch $^{15}$ reported that the overall incidence of serious infection after splenectomy remains low, and the incidence of fulminant OPSI is less, ranging from $0.1 \%$ to $8.5 \%$ overall. Holdsworth ${ }^{16}$ showed that the highest incidence of sepsis after splenectomy (up to $25 \%$ ) caused by hematologic disorders such as thalassemia. Loss of splenic function may explain the increased susceptibility to severe infection after splenectomy, i.e. decreased serum IgM level and tuftsin deficiency, a soluble stimulating factor for neutrophil phagocytosis. ${ }^{4,14}$ Partial splenectomy was performed in order to preserve splenic contribution to the host defence against infections and can be of benefit in treating hypersplenism in children. ${ }^{17}$

A significant association was found between incidence of infection (mild and severe) and splenectomy procedure (OR 3.8; CI=2.26-6.62). Ruth ${ }^{18}$ found no association between common cold and acute diarrhea and the amount of transfusion. The difference between Ruth's and our study is predisposing factors studied. Ruth ${ }^{18}$ studied more on iron overload whereas splenectomy was our concern.

In summary, splenectomy could increase the susceptibility of non transfusion-mediated mild infection in thalassemia. Time after procedure seems to play a role on incidence of infection among thalassemia patients with splenectomy. Further evaluation is needed to elaborate these findings. Our findings still support 3 steps in perioperative management on thalassemia: immunoprophylactic with pneumococ vaccine, antibiotic, and education. ${ }^{19}$

\section{References}

1. Lo L, Singer ST. Thalassemia: Current approach to an old desease. Pediatr Clin North Am 2002;49:1165-91.

2. Wahidiyat I. Transfusi darah pada Thalassemia. In: Gatot D, Abdulsalam M, Windiastuti E. Pendidikan kedokteran berkelanjutan Ilmu Kesehatan Anak XLI. Darah dan tumbuh kembang: Aspek transfusi. Jakarta, 24-25 Juni, 1998; p. 41-6.

3. Pearson HA, Cohen AR, Giardina PJ, Kazazian HH. The changing profile of homozygous b-thalassemia: Demography, ethnicity, and age distribution of current North American patients and changes in two dicades. Pediatrics 1996;97:352-6.

4. Wanachiwanawin W. Infections in E- $\beta$ Thalassemia. J Pediatr Hematol Oncol 2000;22:581-7.

5. Brock JH. Iron and the immune system. In: Lauffer $\mathrm{RB}$, editor. Iron and human disease. Florida: CRC Press, 1992. p. 161-78.

6. Saigean M, Abdee J, Zaman-Vaziree M, Khajehian A. Comparison of neuthrophil function in patient with thalassemia major and healthy control. Arch Iranian Med 2002;5(3):175-8.

7. Khan AJ, Lee CK, Wolff JA, Chang H, Khan P, Evans HE. Defects of neutrophil chemotaxis and random migration in thalassemia major. Pediatrics 1977; 60:349-51.

8. Styrt B. Infection associated with asplenia: Risk, mechanisms, and prevention. Am J Med 1990; 88(5N):33-42N.

9. Emond AM, Morais P, Venugopal S, Carpenter RG, Serjeant GR. Role of splenectomy in homozygous sickle cell disease in chilhood. Lancet 1984;14:88-90.

10. Cohen AR. Infections in Thalassemia Intermedia. Presented at Thalassemia Intermedia: A region I Conference. Boston; 1996 November 14. 


\section{Paediatrica Indonesiana}

11. Lynch A, Tobias JD. Life-threatening infection in two children with hemoglobin S-beta-thalassemia. J Pediatr 1995; 126:581-2

12. Al-Salem AH, Qaisaruddin S, Nasserallah Z, Al Dabbous I, Al Jam'a A. Splenectomy in patients with sickle-cell disease. Am J Surg 1996;172:254-8.

13. Al-Salem, Naserullah Z, Qaisaruddin S, Al-Dabbous I, Al Abkari H, Al-Jam'a A, et al. Splenectomy for hematological diseases: The qatif central hospital experience. Ann Saudi Med 1999;19(4):325-30.

14. Spirer Z, Zakuth V, Diamant S, Mondorf W, Stefanescu T, Stabinsky Y, et al. Decreased tuftsin concentrations in patients who have undergone splenectomy. Br Med J 1977;2:1574-6.
15. Lynch AM, Kapila R. Overwhelming postsplenectomy infection. Infect Dis Clin North Am 1996;10:693-707.

16. Holdsworth RJ, Irving AD, Cushieri A. Post splenectomy sepsis and its mortality rate: Actual versus perceived risk. Br J Surg 1991:78;1031.

17. Nouri A, Montalembert M, Revillion Y, Girot R. Partial splenectomy in sickle cell syndromes. Arch Dis Child 1991;66:1070-2.

18. Ruth AD. Kekerapan sakit infeksi non transfusi pada penderita thalassemia $\beta$ mayor di RSCM [thesis]. Jakarta: University of Indonesia; 2002.

19. Williams, DN, Kaur B. Postsplenectomy care strategy to decrease the risk of infection. Postgrad Med 1996; 100:195-8. 